\title{
RP-HPLC analysis for the simultaneous estimation of rabeprazole sodium and aceclofenac in a combined dosage form
}

\author{
*Sukhbir Lal Khokra, Balram Choudhary, Heena Mehta \\ Institute of Pharmaceutical Sciences, Kurukshetra University, Kurukshetra, Haryana, India
}

\begin{abstract}
A rapid, simple and highly sensitive reversed phase high performance liquid chromatographic (RP-HPLC) method has been developed for the quantitative determination of Rabeprazole sodium and Aceclofenac in a combined dosage form. Rabeprazole sodium and Aceclofenac were chromatographed using C-18 column as stationary phase and methanol: acetonitrile: water $(60: 10: 30 \mathrm{v} / \mathrm{v} / \mathrm{v})$ as the mobile phase at a flow rate of $1.0 \mathrm{ml} / \mathrm{min}$ at ambient temperature and detected at $280 \mathrm{~nm}$. The retention time (RT) of Rabeprazole sodium and Aceclofenac were found to be 5.611 min and 2.102 minute, respectively. The linearities of Rabeprazole sodium and Aceclofenac were in the range of 1-10 $\mu \mathrm{g} / \mathrm{ml}$ and 3-15 $\mu \mathrm{g} / \mathrm{ml}$, respectively. The limit of detection was found to be $0.091 \mu \mathrm{g} / \mathrm{ml}$ for Rabeprazole sodium and $0.043 \mu \mathrm{g} / \mathrm{ml}$ for Aceclofenac. The proposed method was applied for the determination of Rabeprazole sodium and Aceclofenac in a combined dosage form and result was found satisfactory.
\end{abstract}

Key Words: Quantitative analysis, validation, capsule, standard addition method, anti-inflammatory, analgesic.

\section{INTRODUCTION}

Rabeprazole sodium (figure 1 ) is chemically sodium salt of 2-[[[4-(3-methoxypropoxy)-3-methyl-2pyridinyl] methyl] sulfinyl]-1H-benzimidazole and used as antiulcer agent (Merck index, 2001). It is a proton pump inhibitor, which suppresses gastric acid secretion by specific inhibition of the gastric $\mathrm{H}^{+} / \mathrm{K}^{+} /$ATPase enzyme at the secretory surface of the gastric parietal cells (Patel et al., 2007). Aceclofenac (figure 2) is chemically [[[2-[(2, 6-Dichlorophenyl) amino] phenyl] acetyl] oxy] acetic acid and has antiinflammatory and analgesic properties (Indian Pharmacopoeia, 2007). Aceclofenac directly blocks prostaglandin (PGE2) secretion at the site of inflammation by inhibiting interleukin (IL1) and tumour necrosis factor (TNF) in the inflammatory cells (intracellular action) (Garg et al., 2006). Literature review reveals that Spectrophotometric (Kousy et al., 1999; Zawilla et al.,2002; Rahman et al., 2008; ElGindy et al., 2003; Shah et al., 2008; Mishra et al.,

\footnotetext{
*Corresponding Author:

Dr. Sukhbir Lal Khokra, Assistant Professor

Institute of Pharmaceutical Sciences

Kurukshetra University, Kurukshetra

Haryana, India

E-mail:khokrasl@gmail.com

Contact No.: 09416126086
}

2006) HPLC (Singhvi et al., 2007; Park et al., 2008; Ramakrishna et al., 2005; Srinivas et al., 2009; Uno et al., 2005; Singh et al., 2004; Rao et al., 2006; Kulkarni et al., 2006; Jin et al., 2006; Bhinge et al., 2008; Hinz et al., 2006; Musmade et al., 2008) and HPTLC (Joshi et al., 2008) methods have been reported for estimation of individual drugs or in combination with other drugs in formulation. So far no simultaneous method has been reported as this was a new combined dosage form. A single, simple and precise method was to be explored for estimation of Rabeprazole sodium and Aceclofenac in a combined dosage form by RP-HPLC. Therefore, the aim of this work was to develop a RP-HPLC method for the determination of Rabeprazole sodium and Aceclofenac in a combined formulation.

\section{MATERIALS AND METHODS}

Rabeprazole sodium and Aceclofenac pure samples were procured as gift samples from Ranbaxy Laboratories Ltd., Gurgaon. Acetonitrile, methanol and water (HPLC grade, Merck chem. Ltd.) were used for mobile phase preparation and as solvents. Altraday ${ }^{\circledR}$ capsules (Ranbaxy Laboratories Ltd., Mumbai), which were claimed to contain $20 \mathrm{mg}$ of 


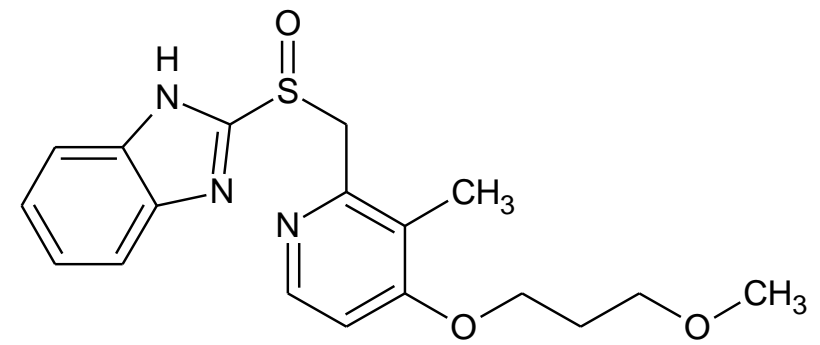

Figure 1. Structure of Rabeprazole.

Rabeprazole sodium IP and $200 \mathrm{mg}$ of Aceclofenac IP, were procured from a local market. An Agilent HPLC1200 instrument equipped with UV-Visible detector, manual injector of $50 \mu \mathrm{L}$ loop and column Pursuit C-18 (250 mm x 4.6 mm i.d., $5 \mu \mathrm{m}$ particle size) was used, a weighing balance (Afcoset ER 200A) and a sonicator were used for the study.

\section{Chromatographic conditions}

Chromatographic estimations were performed under the following conditions: Pursuit C-18 column ( $250 \mathrm{~mm} \times 4.6 \mathrm{~mm}$ i.d., $5 \mu \mathrm{m}$ ) was used at ambient temperature. The mobile phase comprised methanol: acetonitrile: water (60: 10: $30 \mathrm{v} / \mathrm{v} / \mathrm{v}$ ) was pumped at a flow rate of $1 \mathrm{ml} / \mathrm{min}$. The mobile phase was filtered through Nylon $0.45 \mu \mathrm{m}, 47 \mathrm{~mm}$ membrane filter and was degassed before use. The elution was monitored at $280 \mathrm{~nm}$. The injection volume was $10 \mu \mathrm{l}$.

Preparation of combined standard solution of rabeprazole sodium and aceclofenac

Accurately weighed $2 \mathrm{mg}$ Rabeprazole sodium and $20 \mathrm{mg}$ of Aceclofenac were transferred to $100 \mathrm{ml}$ volumetric flask. It was dissolved with sufficient methanol and diluted up to mark with methanol to give concentration of $20 \mu \mathrm{g} / \mathrm{ml}$ of Rabeprazole sodium and $200 \mu \mathrm{g} / \mathrm{ml}$ of Aceclofenac. Above solution was further diluted with the same solvent to get the concentration of $1.5 \mu \mathrm{g} / \mathrm{ml}$ of Rabeprazole sodium and $15 \mu \mathrm{g} / \mathrm{ml}$ of Aceclofenac in the mixture.

\section{Preparation of Calibration Curve}

Standard and sample solutions were injected in a column with $50 \mu \mathrm{l}$ micro-syringe. The chromatogram was run for appropriate minutes with mobile phase, methanol: acetonitrile: water (60:10:30 v/v/v) which was previously degassed, detection was carried out at wavelength $280 \mathrm{~nm}$. The chromatogram was stopped after separation achieved<smiles>O=C(O)COC(=O)Cc1ccccc1Nc1c(Cl)cccc1Cl</smiles>

Figure 2. Structure of Aceclofenac.

completely. Data related to peak like area, height, retention time, resolution etc was recorded using Chemstation software. Calibration curves were constructed by plotting peak areas versus concentrations of Rabeprazole sodium and Aceclofenac and the regression equations were calculated. The calibration curves were plotted over a concentration range $1-10 \mu \mathrm{g} / \mathrm{ml}$ and $3-15 \mu \mathrm{g} / \mathrm{ml}$ for Rabeprazole sodium and Aceclofenac respectively.

\section{Analysis of Pharmaceutical Formulation:}

Twenty capsules were weighed and the average weight of capsule was determined. Contents were finely powdered by mortar and pestle. The powder equivalent to about $20 \mathrm{mg}$ of Aceclofenac and $2 \mathrm{mg}$ of Rabeprazole sodium was taken in a $100 \mathrm{ml}$ volumetric flask, dissolved and diluted up to mark with methanol. It was then ultrasonicated for 10 minutes. The solution was filtered through Wattman filter paper no.42 and first few drops of filtrate were discarded. $0.75 \mathrm{ml}$ of the filtrate was diluted to $10 \mathrm{ml}$ with methanol to get the concentration of 1.5 $\mu \mathrm{g} / \mathrm{ml}$ of Rabeprazole sodium and $15 \mu \mathrm{g} / \mathrm{ml}$ of Aceclofenac. $10 \mu \mathrm{l}$ of this solution was injected into the instrument and chromatographed. The amount of Rabeprazole sodium and Aceclofenac present in the sample solutions were determined by fitting area values of peaks corresponding to Rabeprazole sodium and Aceclofenac to the equations of the line representing the calibration curve of Rabeprazole sodium and Aceclofenac. All determinations were performed in triplicate.

\section{RESULTS AND DISCUSSION}

Rabeprazole sodium and Aceclofenac are soluble in methanol; therefore methanol was selected as the comman solvent. The formulation was dissolved in methanol with sonication for 10 minutes to ensure complete release of drug from the formulation 
Table 1. Summary of the validation parameters of the proposed RP-HPLC method.

\begin{tabular}{lll}
\hline Parameters & $\begin{array}{l}\text { Rabeprazole } \\
\text { sodium }\end{array}$ & Aceclofenac \\
\hline Linearity range $(\mu \mathrm{g} / \mathrm{ml})$ & $1-10$ & $3-15$ \\
Correlation coefficient & 0.9998 & 0.9997 \\
LOD $^{\mathrm{a}}(\mu \mathrm{g} / \mathrm{ml})$ & 0.091 & 0.043 \\
$\mathrm{LOQ}^{\mathrm{b}}(\mu \mathrm{g} / \mathrm{ml})$ & 0.305 & 0.142 \\
Accuracy $(\%)^{\text {Precision }(\% \mathrm{RSD})}$ & $100.7-101.5$ & $100.1-100.8$ \\
Intraday $\left(\mathrm{n}^{\mathrm{d}}=3\right)$ & & \\
Interday $(\mathrm{n}=3)$ & $0.54-0.69$ & $0.27-0.57$ \\
LOD $^{\mathrm{a}}=$ Limit of detection, $\mathrm{LOQ}^{\mathrm{b}}=$ Limit of quantification, \\
RSD $^{\mathrm{c}}=$ Relative standard deviation, $\mathrm{n}^{\mathrm{d}}=$ number of determination
\end{tabular}

matrix. The mixture of methanol: acetonitrile: water (60: $10: 30 \mathrm{v} / \mathrm{v} / \mathrm{v}$ ) could resolve Rabeprazole sodium and Aceclofenac with a better peak shape. The combination of this mobile phase offered optimum separation (5.611 min for Rabeprazole sodium and $2.102 \mathrm{~min}$ for Aceclofenac) and resolution (Figure 3). The linearity of Rabeprazole sodium and Aceclofenac were in the range of $1-10 \mu \mathrm{g} / \mathrm{ml}$ and $3-15 \mu \mathrm{g} / \mathrm{ml}$, respectively, with correlation coefficients of 0.9998 for Rabeprazole sodium and 0.9997 for Aceclofenac. The average linear regression equation was represented as $\mathrm{y}=35.918 \mathrm{x}+$ 2.6676 for Rabeprazole sodium and $y=19.993 x+$ 0.395 for Aceclofenac, where $x$ is the concentration of drug and $y$ is the peak area. The limit of detection was found to be $0.091 \mu \mathrm{g} / \mathrm{ml}$ for Rabeprazole sodium and $0.043 \mu \mathrm{g} / \mathrm{ml}$ for Aceclofenac. The limit of quantification was found to be $0.305 \mu \mathrm{g} / \mathrm{ml}$ for Rabeprazole sodium and $0.142 \mu \mathrm{g} / \mathrm{ml}$ for Aceclofenac. The intraday precision (RSD) was determined for standard Rabeprazole sodium and Aceclofenac three times on the same day and interday precision was calculated for standard Rabeprazole sodium and Aceclofenac, three times over a period of one week. The intraday and interday coefficients of variation for both drugs were found to be in the range of $0.27-0.83 \%$ and $0.54-0.81 \%$, respectively. These values indicate that the method is precise. The accuracy of the method was evaluated by calculating the recovery of Rabeprazole sodium and Aceclofenac by a standard addition method at 3 levels of the calibration curve $(n=3)$. The percentage recovery was found to be $100.7-101.5 \%$ for Rabeprazole sodium and $100.1-100.8 \%$ for Aceclofenac, ensuring that the method is accurate. Various validation parameters for the proposed RP-HPLC

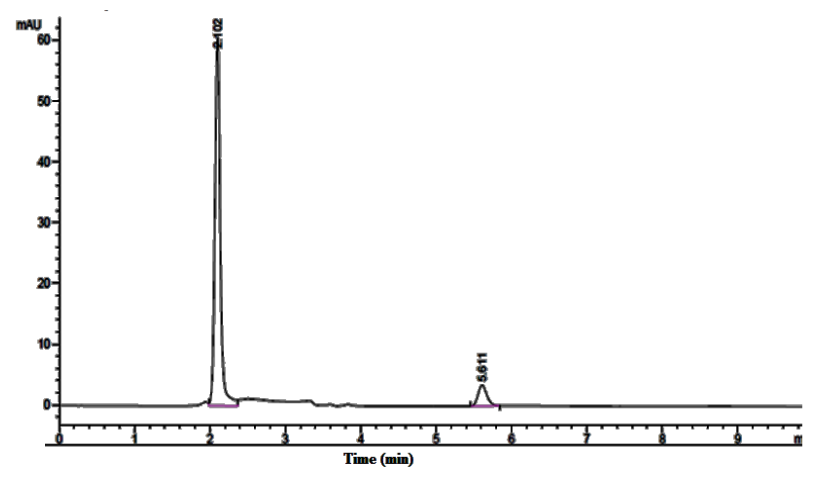

Figure 3: Chromatogram showing retention time of Rabeprazole sodium and Aceclofenac.

method for determining the Rabeprazole sodium and Aceclofenac contents in their combined marketed formulation and are summarized in Table 1. Potency determination of marketed capsule formulation by proposed method furnished results of $101.08 \pm 0.36 \%$ and $100.72 \pm 0.40 \%$ for Rabeprazole sodium and Aceclofenac, respectively. Analysis result indicates that the proposed RP-HPLC method is simple, rapid, precise and accurate for the simultaneous estimation of Rabeprazole sodium and Aceclofenac in its combined formulation.

\section{ACKNOWLEDGEMENT}

The authors are grateful to Ranbaxy Laboratories Ltd., Gurgaon for providing standard drug samples and also to Director, Institute of Pharmaceutical Sciences, Kurukshetra University, Kurukshetra for providing the required facilities.

\section{REFERENCES}

Bhinge JR, Kumar RV, Sinha VR. (2008) A simple and sensitive stability indicating RP-HPLC assay method for the determination of Aceclofenac. J Chromatogr Sci; 46(5): 440-444.

El Kousy NM. (1999) Spectrophotometric and spectrofluorimetric determination of Etodolac and Aceclofenac. J Pharm and Biomed Anal; 20(1-2): 185-194.

El-Gindy A, El-Yazby F, Maher MM. (2003) Spectrophotometric and Chromatographic determination of Rabeprazole in presence of its degradation products. J Pharm and Biomed Anal; 31(2): 229-242.

Garg, G., Deependra Singh, Saraf Swarnlata, Saraf S. (2006) Aceclofenac: A Potent Non-Steroidal Anti-Inflammatory Drug, pharmainfo.net, Vol. 4 Issue 3. [LINK] 
Hinz B, Auge D, Rau T, Rietbrock S, Brune K et al. (2003) Simultaneous determination of Aceclofenac and three of its metabolites in human plasma by high performance liquid chromatography. Biomed Chromatogr; 17(4): 268275 [DOI]

Indian Pharmacopoeia, Controller of Publication, Govt. of India, Ministry of Health and Family Welfare, New Delhi, 2007, Vol. 3, 1647.

Jin Y, Chen H, Gu S, Zeng F. (2004) Determination of Aceclofenac in human plasma by reversed phase high performance liquid chromatography. Chinese J Chromatogr; 22(3): 252-254.

Joshi R, Sharma R. (2008) Development and validation of RPHPLC method for simultaneous estimation of three component tablet formulation containing Acetaminophen, Chlorzoxazone and Aceclofenac. Anal Letters; 41(18): 3297-3308 [DOI]

Kulkarni VL, Mahulikar PP. (2006) Estimation of Rabeprazole sodium in tablet dosage form by rapid isocratic reversed phase high performance liquid chromatography using volatile buffer additives. J Scientific \& Ind Res; 65: 992-994.

Merck index, Merck and Co. Inc. London: White House Station, 13th ed, 2001, 1450.

Mishra P, Garg G. (2006) Spectrophotometric estimation of Aceclofenac in tablets. J Indian chem. society; 83(1): 103104.

Musmade P, Subramanian G, Srinivasan KK. (2007) High performance liquid chromatography and pharmacokinetic of Aceclofenac in rats. Anal Chemica Acta; 585(1): 103-109 [DOI]

Park CW, Rhee YS, Go BW, Kam SH, Lee KH, Lee HS, et al. (2008) High performance liquid chromatographic analysis of Rabeprazole in human plasma and its pharmacokinetic application. Arch Pharm Res; 31(9): 1195-1199 [DOI]

Patel BH, Suhagia BN, Patel MM, Patel JR. (2007) HPLC Analysis for simultaneous determination of Rabeprazole and Domperidone in pharmaceutical formulation. J Liq Chromatogr \& Rel Tech; 30(3): 439-445 [DOI]

Rahman N, Bano Z, Azmi SNH. (2008) Quantitative analysis of Rabeprazole sodium in commercial dosage forms by spectrophotometry. Chem. Pharm. Bull; 56(7): 995-1001 [DOI]

Ramakrishna NVS, Vishwottam KN, Wishu S, Koteshwara M, Kumar SS. (2005) High performance liquid chromatography method for the quantification of Rabeprazole in human plasma using solid phase extraction. J Chromatogr; 816(1-2): 209-214. [DOI]

Rao RN, Raju AN, Nagaraju D. (2006) Enantiospecific resolution of Rabeprazole by liquid chromatography on amylose derived chiral stationary phase using photo diode array and polarimetric detectors in series. Talanta; 70(4): 805-810.
Shah R, Magdum C, Patil S, Chougule D, Naikwade N. (2008) Validated spectroscopic method estimation of Aceclofenac from tablet formulation. Research J Pharm and Tech.; 1(4): 430-432.

Singh SS, Jain M, Shah H, Gupta S, Thakker P, Shah R. (2004) Direct injection, column switching liquid chromatographic technique for the estimation of Rabeprazole in bioequivalence study. J Chromatogr B; 813(1-2): 247-254 [DOI]

Singhvi I, Goyal A. (2007) Visible Spectrophotometric estimation of Aceclofenac and Indapamide from tablets using folin-ciocalteu reagent. Indian J Pharm Sci; 69(1): 164-165 [DOI]

Srinivas KSV, Buchireddy R, Mukkanti K, Srinivasulu P. (2009) A validated RP-LC method for advanced intermediate of Rabeprazole sodium. Chromatographia; 69(3-4): 381-384 [DOI]

Uno T, Yasui-Furukori N, Shimizu M, Sugawara K, Tateishi T. (2005) Determination of Rabeprazole and its active metabolite, Rabeprazole thioether in human plasma by column switching high performance liquid chromatography and its application to pharmacokinetic study. J Chromatogr B; 824(1-2): 238-243. [DOI]

Zawilla NH, Azim MA, El Kousy NM, El-Moghazy Aly SM. (2002) Determination of Aceclofenac in bulk and pharmaceutical formulations. J Pharm and Biomed Anal; 27(1-2): 243-251. [DOI] 